NBER WORKING PAPER SERIES

\title{
WAS POSTWAR SUBURBANIZATION "WHITE FLIGHT"? EVIDENCE FROM THE BLACK MIGRATION
}

\author{
Leah Platt Boustan \\ Working Paper 13543 \\ http://www.nber.org/papers/w13543 \\ NATIONAL BUREAU OF ECONOMIC RESEARCH \\ 1050 Massachusetts Avenue \\ Cambridge, MA 02138 \\ October 2007
}

I appreciate helpful suggestions from Edward Glaeser (editor), two anonymous referees, my dissertation committee (Claudia Goldin, Caroline Hoxby, Lawrence Katz and Robert A. Margo), and numerous colleagues at UCLA. I enjoyed productive conversations with Lee Alston, David Clingingsmith, William J. Collins, Carola Frydman, Christopher Jencks, Jesse Rothstein, Albert Saiz and Raven Saks. I received useful comments from seminar participants at the All-UC Conference for Labor Economics, the Federal Reserve Bank of Philadelphia, the KALER group at UCLA, New York University's Wagner School of Public Service, the Society of Labor Economists, the University of British Columbia, UC-Berkeley's Goldman School of Public Policy, the University of Chicago Booth School of Business and the Wharton School. Michael Haines generously shared some of the data used in this study. Financial support was provided by the National Science Foundation Graduate Research Fellowship and the Multi-disciplinary Program on Inequality and Social Policy at Harvard University. The views expressed herein are those of the author(s) and do not necessarily reflect the views of the National Bureau of Economic Research.

(C) 2007 by Leah Platt Boustan. All rights reserved. Short sections of text, not to exceed two paragraphs, may be quoted without explicit permission provided that full credit, including $\odot$ notice, is given to the source. 
Was Postwar Suburbanization "White Flight"? Evidence from the Black Migration

Leah Platt Boustan

NBER Working Paper No. 13543

October 2007, Revised June 2009

JEL No. J61,N12,R23

\section{ABSTRACT}

Residential segregation by jurisdiction generates disparities in public services and education. The distinctive American pattern - in which blacks live in cities and whites in suburbs - was enhanced by a large black migration from the rural South. I show that whites responded to this black influx by leaving cities and rule out an indirect effect on housing prices as a sole cause. I instrument for changes in black population by using local economic conditions to predict black migration from southern states and assigning predicted flows to northern cities according to established settlement patterns. The best causal estimates imply that each black arrival led to 2.7 white departures.

Leah Platt Boustan

Department of Economics

8283 Bunche Hall

UCLA

Los Angeles, CA 90095-1477

and NBER

lboustan@econ.ucla.edu 


\section{Introduction}

American metropolitan areas are segregated by race, both by neighborhood and across jurisdiction lines. In 1980, after a century of suburbanization, 72 percent of metropolitan blacks lived in central cities, compared to 33 percent of metropolitan whites. Because many public goods are locally financed, segregation between the central city and the suburbs can generate disparities in access to education and other public services (Benabou, 1996; Bayer, McMillan and Rueben, 2005). These local disparities have motivated large policy changes over the past fifty years, including school finance equalization plans within states and federal expenditures on education.

Racial segregation by jurisdiction has historical roots in two population flows: black migration from the rural South and white relocation from central cities to the suburban ring. Both flows peaked during World War II and the subsequent decades. Between 1940 and 1970, four million black migrants left the South, increasing the black population share in northern and western cities from four percent in 1940 to 16 percent in 1970 . Over the same period, the median non-southern city lost ten percent of its white population.

This paper shows that white departures from central cities were, in part, a response to black in-migration. ${ }^{1}$ In every decade, cities that received a larger flow of black migrants also lost a larger number of white residents. Figure 1 provides an initial look at the relationship between black arrivals and white departures in non-southern cities over the 1950s. The slope of the regression line through these points suggests that each black arrival was associated with two white departures.

\footnotetext{
${ }^{1}$ An extensive literature argues that white households have a preference for white neighbors. See Ellen (1999), Crowder (2000), Emerson, Chai and Yancey (2001) and the references contained therein. Boustan (2007) shows that demand for urban residence is also affected by city-wide demographics.
} 
The relationship between black arrivals and white departures provides suggestive evidence of "white flight," a process by which white households left central cities to avoid living in racially diverse neighborhoods or jurisdictions. However, the correlation between black arrivals and white departures could also be driven by the potentially endogenous location decisions of southern black migrants. If whites left particular northern cities for other reasons (for example, due to the construction of a new interstate highway), migrants may have been attracted by lower housing prices left in the wake of white departures (Gabriel, Shack-Marquez and Wascher, 1992; Saiz, 2007). ${ }^{2}$ Alternatively, migrants may have flocked to areas with high wages or centrally-located manufacturing jobs, factors that also underlie the demand for suburban residence (Margo, 1992; Steinnes, 1977; Thurston and Yezer, 1994).

I employ an instrumental variables procedure to address these potential alternatives. The instrument makes use of the fact that black migrants from given southern states clustered in particular northern cities. As a result, northern cities received exogenous flows of black migrants when their traditional southern sending states underwent agricultural and economic change. In particular, I use variation in local agricultural conditions to predict black out-migration from southern states and assign these predicted migrant flows to northern cities using settlement patterns established by an earlier wave of black migration. These predicted changes in black population serve as an instrument for actual black in-migration.

After adjusting for migrant location choices, I estimate that each black arrival was associated with 2.7 white departures. The median city, which had 200,000 white residents, absorbed 19,000 black migrants over this period. My estimates imply that these arrivals prompted the departure of 52,000 white residents, resulting in a 17 percent net decline in the

\footnotetext{
${ }^{2}$ Gamm (1999) argues that black migrants were attracted to the Dorchester and Roxbury neighborhoods of Boston by the decline in housing prices following a wave of Jewish suburbanization.
} 
urban population. While primarily driven by household mobility, I find that the decline in white population is also partly due to a reduction in the size of remaining white households.

Observing white departures in response to black arrivals is not sufficient evidence to demonstrate the presence of white flight. White departures may be prompted by the fact that black migrants bid up the price of city housing units. In a simple spatial model, I demonstrate that if white households have no distaste for racial diversity, each black arrival will lead to one white departure with no long-run effect on housing prices. In contrast, if white households have a distaste for racial diversity, black migration will be associated with more than one white departure for every black arrival, declining urban population and, in some cases, falling housing prices. I show that in otherwise declining areas, black migration leads to an increase in the vacancy rate and an associated decline in housing prices. In growing areas, black migration instead slows the rate of new home construction, leading to a smaller housing stock with no effect on housing prices.

Early studies of urban population loss suggest that households left cities to escape mounting urban problems, including a rising crime rate, fiscal mismanagement, and a growing concentration of racial minorities and the poor (Bradford and Kelejian, 1973; Guterbock, 1976; Frey, 1979; Marshall, 1979; Grubb, 1982; Mills and Price, 1984; Mieszkowski and Mills, 1993). These papers find mixed evidence for the relationship between urban racial diversity and suburbanization in 1960 or 1970 cross sections. Recent studies put more emphasis on transportation improvements, including the automobile and new road building, which reduce the time cost of commuting from bedroom communities (LeRoy and Sonstelie, 1983; Baum-Snow, 
2007; Kopecky and Suen, 2007). ${ }^{3}$ The decline in urban population following the typical black inmigration found here is equivalent to Baum-Snow's (2007) estimates of the decline in urban population after the construction of one new highway through the central city.

This paper documents that black arrivals reduced the overall demand for city residence in the mid-twentieth century, leading to white out-migration and, in some cases, falling housing prices. However, the mechanisms by which cities lost their luster are less clear. Because poverty and race are highly correlated, I cannot distinguish here between a distaste for the race or the income level of southern arrivals. Moreover, with a metropolitan area-level analysis, I cannot separate changes to local neighborhoods and school from changes to city-wide characteristics, including the property tax rate and local spending priorities. Card, Mas and Rothstein (2008) demonstrate that neighborhoods can "tip" from white to minority areas after reaching a critical minority share. However, because cities were highly segregated by neighborhood, few neighborhoods fell into the range in which they would be at risk to tip. I find that, at most, 20 percent of the estimated white departures can be traced to neighborhoods in the tipping range. Exploring other mechanisms for white departures is a fruitful area for future research.

\section{White Flight in a Simple Spatial Model}

In the postwar period, black migrants settled disproportionately in central cities. This section illustrates potential channels by which black arrivals may have affected both the number of white residents and housing prices in receiving cities. The model demonstrates that, as long as housing supply is not perfectly elastic, some white departures will occur even without a distaste

\footnotetext{
${ }^{3}$ An exception is Cullen and Levitt (1998) which studies the relationship between crime rates in the central city and suburbanization. Historians continue to emphasize the connection between racial diversity and suburbanization (Jackson, 1985; Sugrue, 1996; Meyer, 2000).
} 
for racial diversity due to the effect of new arrivals on housing prices. ${ }^{4}$ However, if whites have some distaste for living near blacks, black migration will be associated with declining urban population and, in some cases, falling housing prices.

Consider a central city in the North with a given number of white households. With free mobility, utility in this city cannot fall below $\underline{\mathrm{u}}$, the utility level for a white household in the suburban ring of the city's own metropolitan area and in other metropolitan areas around the country. Household utility can be written:

$$
\mathrm{U}(\mathrm{p}, \mathrm{b}, \mathrm{z})=\underline{\mathrm{u}}
$$

$\mathrm{U}$ is decreasing both in the price of housing (p) and (weakly) in the share of the city residents that are black $(b=B /(B+W)$, where $B$ and $W$ are the number of black and white households, respectively). $\mathrm{z}$ is a demand shifter representing either local amenities or productivity. The price of housing is a function of the number of households in the city, $\mathrm{N}(\mathrm{N}=\mathrm{W}+\mathrm{B})$. The sensitivity of price to the number of households is determined by $\varphi$, the price elasticity of housing supply.

Initially, all blacks live in the South. Blacks will migrate to the North if their utility level in the northern city is higher than some reservation southern utility. Southern utility $\underline{s}$ is determined by the wage rate in southern agriculture (w), which is decreasing in number of blacks in South. The utility function of a black household in the North is identical to that of a white household, except that black utility may be increasing in the number of blacks in the city:

$$
\mathrm{U}(\mathrm{p}, \mathrm{b}, \mathrm{z})=\underline{\mathrm{s}}(\mathrm{w})
$$

The price elasticity of housing supply $(\varphi)$ is determined by the decisions of a profit maximizing construction sector. For prices below construction cost (c), each unit built yields

\footnotetext{
${ }^{4}$ A distaste for racial diversity could arise either directly from racist attitudes or indirectly from concerns about local amenities such as crime rates or school quality.
} 
negative profits. In this region, firms will not build new units and the housing supply elasticity is zero. In the simplest case, housing supply will be perfectly elastic at price equal to construction cost. Alternatively, we could imagine that the city rations building permits. To build an additional unit, firms must incur a lobbying cost $\mathrm{L}(\mathrm{N})$, which is increasing in the size of the city. In this case, housing supply elasticity will be positive but not infinite at prices above construction cost. This kinked supply curve generates an asymmetric response to changes in demand: increasing demand leads to new construction but declining demand does not lead to an (immediate) reduction in the housing stock (Glaeser and Gyourko, 2005).

The city is in spatial equilibrium when all white and black residents weakly prefer their own location over the alternatives and when firms in the construction sector earn zero profits. Spatial equilibrium determines a city housing price $\mathrm{p}^{*}$, which will be equal to or below construction costs, and the share of the city residents who are black $\left(b^{*}\right)$.

How will the city respond to an influx of black arrivals? Consider a decline in southern wages following mechanization in the agricultural sector, prompting black migration to the city. This case corresponds to the instrument for black migration described in the next section, which relies on exogenous variation in southern agricultural conditions. When $\underline{s}$ falls, black migrants move to the city. Migration continues until the southern wage rises sufficiently to make blacks indifferent between the South and the North. The city's construction sector responds to the new arrivals. If housing supply is perfectly elastic at prices above construction costs, firms will build new units until prices return to $\mathrm{p}^{*}=\mathrm{c}$ and no white households will leave the city. If housing supply is less than perfectly elastic, housing prices will increase somewhat with black inmigration, encouraging some white households to leave the city in response. 
How many whites will leave the city in this scenario? To begin with, assume that whites have no distaste for black residents $\left(\mathrm{U}_{\mathrm{b}}^{\prime}=0\right)$. According to equation 1 , spatial equilibrium for white households will only be restored when city prices return to $\mathrm{p}^{*}$. Given that prices are a function of the total number of households in the city, this relationship holds when each black arrival displaces exactly one white resident. From this reasoning, we can conclude that: If whites exhibit no distaste for racial diversity (and housing supply is not perfectly elastic), black migration to a central city will lead to: (a) exactly one white departure for every black arrival and (b) no long-run change in city housing prices.

Black migration increases both housing prices and the black population share in the city. If white households dislike racial diversity $\left(\mathrm{U}_{\mathrm{b}}<0\right)$, black migration will prompt more white departures than in the previous case. This decline in city population will lead housing prices to fall below construction costs. The housing stock will decline at some rate $\lambda$ until prices eventually return to $\mathrm{p}^{*}{ }^{5}$ From this reasoning, we can conclude that: If whites exhibit a distaste for racial diversity, black migration to a central city will lead to: (a) more than one white departure for every black arrival and (b) a short-run decline in city housing prices.

Define $\lambda$ as the (exogenous) speed with which city housing prices return to $\mathrm{p}^{*}$, either through depreciation of the existing housing stock or a slowdown in new construction. In cities that are otherwise expanding, the housing stock can easily decline (in a relative sense) through a slowing of the rate of new construction. That is, expanding cities are characterized by a high $\lambda$. However, in cities that are otherwise shrinking, a decline must occur through a slower process of the depreciation of the existing housing stock. This distinction generates an additional prediction: In declining areas, white departures will be coupled with a high vacancy rate and falling prices,

\footnotetext{
${ }^{5}$ In the meantime, low housing prices in the city will induce additional black migration which, in turn, will prompt more white departures. The city will not tip from all white to all black because the loss of black population from the South will increase southern wages, eventually bringing migration to a halt.
} 
whereas in growing areas, white departures will lead to a decline in the rate of new construction and housing prices will remain at construction costs.

The model suggests a set of empirical relationships to be explored in the data. First, white departures from the central city will respond to the number of black arrivals - rather than the percentage change in the black population. However, spatial equilibrium for white households indicates that housing prices will respond to the black share of the city's population, rather than by the number of black arrivals. If the number of white departures with every black arrival is statistically greater than one, we can rule out housing prices as a sole cause of the white outflow.

Thus far, I have considered how the urban equilibrium is affected by black migration pushed from the South by a decline in southern wages. However, changes to the northern city itself may also attract black migrants. An increase in northern productivity (z) could simultaneously attract black migrants and encourage some white households to move to suburbs. ${ }^{6}$ This process could generate a spurious correlation between these two population flows. Alternatively, if whites leave the city for any other reason (modeled as an increase in $\underline{u}$ ), housing prices may fall, encouraging black in-migration from the South. In this case, an association between black arrivals and white departures would not be driven by white racism but rather by black location choice (reverse causality). The spatial model helps to demonstrate the importance of focusing on southern conditions as a source of exogenous variation in black population growth in the North. In next section, I introduce an instrument for black migration using factors that exogenously change the utility of southern blacks.

\footnotetext{
${ }^{6}$ A productivity-driven increase in wages may encourage some white households to move to the suburbs. Living in the suburbs involves a tradeoff between the price of housing services and the distance to work. An increase in income will prompt households to move to the suburbs as long as the elasticity of housing services with respect to income is greater than the income elasticity of the opportunity cost of time (Becker, 1965).
} 


\section{Using southern black migration to instrument for black arrivals to northern cities}

\section{A. Historical context and conceptual approach}

Rural blacks were attracted northward by economic opportunities in the manufacturing and service sectors. The demand-pull component of this migrant flow is undoubtedly correlated with economic conditions in destination cities. Southern push factors can be used to create an instrument for changes in urban diversity in the North. I use local economic conditions to predict black migrant flows from each southern state. These local factors are unlikely to be correlated with aspects of the northern economy. I assign predicted flows to northern destinations using settlement patterns established by an earlier wave of black migration. ${ }^{7}$ The predicted black population in a northern city are used to instrument for the actual black population.

Key to this procedure is the fact that blacks leaving particular southern states settled in certain northern cities. These settlement patterns were highly persistent, in part due to the stability of train routes and community networks. ${ }^{8}$ Much of the variation in source/destination pairs occurs between regions, with migrants simply moving due North - say, from the Mississippi Delta to industrial cities in the Midwest. However, there is also considerable variation within regions. Consider the case of Alabama and Mississippi, two neighboring, cottonproducing states in the traditional "black belt." Figure 2 displays the share of northern black migrants from these two states that settled in various cities between 1935-40. Migration from Mississippi to the North was overwhelmingly concentrated in two destinations, Chicago and St. Louis. Detroit received the largest flow from Alabama, followed by Chicago and Cleveland.

\footnotetext{
${ }^{7}$ The first wave of black migration was prompted by growth in industrial employment during World War I and the imposition of strict immigration quotas in 1924, which slowed migration from Europe (Collins, 1997).

${ }^{8}$ Carrington, Detragiache, and Viswanath (1996) model this type of chain migration as a reduction in the uncertainty costs of migration.
} 
The difference in migration patterns between these neighboring states is consistent with disparities in their railroad infrastructure, which were in place long before 1940. The black population in Mississippi was clustered along the Mississippi river, a region served by only one inter-state railroad (the Illinois Central), whose main hubs were St. Louis and Chicago. In contrast, the large cities in Alabama, Mobile and Birmingham, were each served by two major railroads - the Gulf, Mobile, and Ohio railroad, which connected to the Illinois Central network in St. Louis, and the Alabama Great Southern Railroad, which brought riders east to Cleveland and Detroit. ${ }^{9}$

\section{B. Building an instrument from historical data}

The instrument for northern black population is made up of two components: predicted migrant flows from southern states and the settlement pattern established by blacks leaving these states in an earlier wave of migration. To predict black migration from a southern state, I start by estimating net black migration rates at the county level as a function of agricultural and industrial conditions:

$$
\text { mig_rate }_{c t-t+10}=\alpha+\gamma(\text { push factors })_{c t}+\varepsilon_{c t}
$$

I use county characteristics at the beginning of a decade to predict migration over the subsequent ten-year period because contemporaneous changes in southern economic conditions could be a response to, rather than a cause of, migration (Fligstein, 1981). For instance, planters may scale

\footnotetext{
${ }^{9}$ Grossman (1989, p. 99) writes that "the first [migrant from Mississippi] to leave for Chicago probably chose the city because of its position at the head of the Illinois Central." A map of rail links from the South c. 1915 can be found at http://alabamamaps.ua.edu/historicalmaps/railroads/. See Grossman (1989, p. 66-119) and Gottlieb (1987, p. 39-62) for a broader discussion of the role of train routes and information networks in black migration.
} 
back cotton production as agricultural wages rise with out-migration. I also present results using only 1940 county characteristics to predict migration in each of the three following decades.

Table 1 contains coefficients from the regression of net migration rates on county characteristics. ${ }^{10}$ The results from this exercise coincide with predictions from southern economic history. A county's cotton share strongly predicts black out-migration in the 1940s, as the planting and weeding components of cotton production were mechanized, and again in the 1960s, when a viable cotton harvester diffused throughout the South - but not in the 1950s (Grove and Heinicke, 2003, 2005). ${ }^{11}$ A ten percentage point increase in the share of land planted in cotton predicts six additional out-migrants per 100 black residents in the 1940s and five additional out-migrants in the 1960s. In contrast, agricultural counties in tobacco-growing states, which were slow to mechanize, lost black population only in the 1960s (Wright, 1986). Counties that received federal funds for war-related industry in the 1940s attracted black migrants, though the effect of this war-time spending dissipated by the 1950s. The discovery of major oil fields and the expansion of natural gas attracted black entrants to mining counties in Oklahoma and Texas in the 1940s and 1950s.

I generate a predicted migration flow from each county by multiplying the fitted migration rate by the county's initial black population. These predicted flows are aggregated to the state level $\left(\right.$ pred_mig $\left.g_{s t}\right)$ and allocated to northern cities according to the settlement patterns of blacks who left the state between 1935-40. Let $w_{n s}$ be the share of blacks who left state $s$ after

\footnotetext{
${ }^{10}$ Source details are contained in the Data Appendix and the associated summary statistics are presented in Appendix Table 1.

${ }^{11}$ Federal cotton policy may have spurred the first wave of cotton mechanization in the late 1930s and 1940s. The Agricultural Adjustment Act (AAA) of 1933 encouraged cotton growers to leave fields fallow, a burden they often imposed on their tenants. This policy inadvertently increased the average size of cotton farms, thus providing an incentive to invest in high fixed cost capital goods. See Fligstein (1981, p. 137-151), Whatley (1983), and Wright (1986, p. 226-238). Correspondingly, tenancy rates are an important predictor of out-migration in the 1940s, when the traditional sharecropping system was giving way to wage labor arrangements (Alston, 1981).
} 
1935 and reside in city $n$ in $1940 .{ }^{12}$ The number of black migrants predicted to arrive in city $n$ at time $t$ is thus the sum over the 14 southern states of migrants leaving state $s$ and settling in city $n$ :

$$
\text { pred_mig } g_{n t}=\sum_{s=1 \ldots 14}\left(w_{n s} \cdot \text { pred_mig }{ }_{s t}\right)
$$

I use this predicted in-flow to advance a city's black population forward from 1940, with the predicted black population serving as the instrument for the actual population.

Card (2001), Lewis (2005), and Doms and Lewis (2006) use a similar approach to study the effect of immigration on local labor markets. ${ }^{13}$ One important difference, however, is that these papers allocate the actual inflow of immigrants to cities rather than predicting the inflow from a set of local push factors. As a result, the method assumes that the "total number of immigrants from a given source country who enter the United States is independent of....demand conditions in any particular city" (Card 2001, p. 43). However, given that migrants cluster, a positive economic shock in a destination city could stimulate additional migration flows from source areas. I present results using both actual and predicted migration flows.

\section{The causal relationship between black arrivals and white departures from central cities}

\section{A. Data and Estimation Framework}

I compile a dataset of population and household counts from 1940 to 1970 in 70 large metropolitan areas (SMSAs) in the North and West. ${ }^{14}$ Stacking data from the four Census years, I begin by estimating the relationship between the number of non-black ("white") residents

\footnotetext{
12 The 1940 Census is the first to collect systematic data on internal migration. Aggregate mobility tables are available by race for 53 cities in the sample. The mobility data provide the city and state of residence in 1935 for residents of a given city in 1940 .

${ }^{13}$ In a related approach, Munshi (2003) uses rainfall in Mexican villages as an instrument for the size of different migrant networks in the United States.

${ }^{14}$ I exclude the South because the vast majority of black migrants into southern cities came from the surrounding state, making it difficult to separate changes in urban diversity from periods of local economic change. Sample selection is discussed in more detail in the Data Appendix.
} 
(W_CITY) and the number of black residents (B_CITY) in the central city of these metropolitan areas $(m)$ :

$$
\text { W_CITY }{ }_{m r t}=\alpha_{m}+\beta_{1}(\text { B_CITY } m r t)+\gamma_{1}\left(\text { POP_METRO }{ }_{m r t}\right)+v_{r t}+\varepsilon_{m r t}
$$

where $t$ and $r$ indicate Census decades and regions respectively. ${ }^{15} v_{r t}$ are Census region by decade fixed effects. ${ }^{16} \beta_{1}$ is thus estimated from changes in black population within a city over time, compared to other cities in the region. I control for the size of the metropolitan area (POP_METRO) because growing areas will attract a large flow of both black and white inmigrants. The instrument discussed above is only available for 53 of the sample cities.

Earlier work on the role of race in the suburbanization process compares cross-sections of cities with different black population shares at a point in time. The benefit of a panel is twofold: first, the size of a city's black population may be correlated with fixed aspects of an area's industrial base, transportation network, or housing stock. Such characteristics may also encourage suburban development, leading to a spurious correlation in the cross section. Second, the size of central cities - in land area - relative to their metropolitan areas varies widely. While this variation can obscure comparisons of suburbanization across metropolitan areas, city size is largely unchanging within a metropolitan area over time.

Cities can expand in land area over time by annexing nearby unincorporated land (or, less commonly, neighboring suburbs). My preferred measure of the central city fixes city boundaries according to their 1940 definition, foreclosing the possibility of an endogenous annexation

\footnotetext{
${ }^{15}$ While the model relates the number of white households to the number of black households in a central city, I begin by estimating the relationship between black and white population for two reasons. First, the instrument generates variation at the individual, rather than the household, level. Secondly, I am unable to correct the households counts for possibly endogenous annexation. Table 3 contains household-level results in OLS.

${ }^{16}$ I combine the Western and Mountain Census regions and the New England and Mid Atlantic Census regions into Western and Northeastern regions, respectively.
} 
response to changes in racial diversity (Austin, 1999; Alesina, Baqir and Hoxby, 2004).${ }^{17}$ The Data Appendix discusses alternative definitions of the central city and assesses the robustness of the results to the choice of measure. Summary statistics are presented in Appendix Table 2. The mean city is 9.2 percent black and is located in a metropolitan area with 1.3 million residents, 41 percent of whom live in the city itself.

\section{B. First-stage results}

The stability of migrant settlement patterns generates a strong association between actual changes in black population and changes due to predicted black in-migration alone. The first column of Table 2 reports results from a series of first-stage regressions. In the first row, the instrument is generated by allocating actual southern flows to the North akin to Card (2001) and others. The subsequent rows use predicted migrant flows based on southern push factors. Not surprisingly, the relationship between actual and simulated changes in black population is stronger when assigning actual rather than predicted migrant flows. Each predicted black arrival is associated with 4.4 actual new black residents when assigning real migrant flows (row 1) and 3.5 new black residents when assigning predicted migrant flows (row 2). The coefficient is highly significant in both cases. The magnitudes suggest that, over a decade, each migrant arrival leads to the equivalent of one new black household (assuming the mean household size of 3.5 residents) in the central city, a process that presumably occurs through family formation and child bearing in the North.

Figure 3 graphs the first stage relationship using predicted migrant flows in the 1950s, again controlling for region fixed effects and metropolitan area growth. Larger positive

\footnotetext{
${ }^{17}$ Only five cities in the sample annexed enough territory to expand their populations by at least five percent. These are: Phoenix, AZ; Fresno, Sacramento and San Bernardino, CA; and Wichita, KS.
} 
deviations from the regression line correspond to cities like Baltimore, MD that experienced more black population growth than would be predicted by migration from their typical sending states, perhaps due to positive economic shocks that attracted arrivals from new source areas. The reverse is true of cities like St. Louis, MO that fall below the regression line. In general, the positive relationship between actual and predicted black population growth is strong and is not driven by any obvious outliers.

\section{Second stage results}

The remainder of Table 2 conducts the IV analysis. If migrant location choice were driving the correlation between black arrivals and white departures, the IV estimates should be smaller (less negative) than OLS. A comparison between columns 2 and 3 reveals that the IV point estimates are never markedly different from their OLS counterparts. If anything, the IV coefficients are slightly more negative than OLS, suggesting that black migrants avoided cities that were otherwise losing white population. Interestingly, the results are nearly identical whether I use actual or predicted migrant flows to generate the instrument. ${ }^{18}$

If economic shocks are serially correlated, migrants' destination choices in the late 1930s may be related to local economic conditions in subsequent decade(s). The third row presents IV results for 1950-1970, leaving a full decade between the pre- and post-periods. The fourth row uses 1940 county characteristics to predict out-migration from the South in every decade to avoid changes in the southern economy that could be a response to, rather than a cause of, migration. The results are similar in both cases.

\footnotetext{
${ }^{18}$ While intra-state migration will net out when aggregating actual county-level migration to the state level, the same may not be true with predicted migration. Thus, the predicted state aggregates may erroneously include and assign to the North some internal migrants.
} 
There is no evidence that the correlation between black arrivals and white departures from central cities is due to the endogenous location choices of black migrants. Even after constraining black migrants to follow settlements patterns established in the 1930s, I find that each black entrant leads to 2.3-3.0 white departures. The final two rows of Table 2 examines the long-run implications of black migration for urban population growth. I estimate the relationship between the sixty-year change in the black and non-black population of central cities from 1940 to 2000 , instrumenting for changes in the black population with migration from 1940 to 1970 . In the long run, each black arrival leads to only one non-black departure and, therefore, has no effect on the overall urban population. Over time, some non-black residents without a distaste for racial diversity may have been attracted to these central cities by lower housing prices. The last row of Table 2 shows that the foreign-born, whose numbers have increased greatly since 1970, have contributed to this trend. Each black arrival increased the number of white foreign-born residents in these central city by 0.2 persons, accounting for around 20 percent of the long-run renewal of urban population.

Thus far, I have examined the relationship between black and white residents in central cities, while the model focused on households. The population and household effects could be different if black and white households are systematically different in size. Table 3 contains OLS regressions relating the number of white households in the central city and the average size of remaining white households to black household entry. The arrival of one black household led to the departure of 1.6 white households; we can statistically rule out a displacement rate of onefor-one. Black arrivals also led to a reduction in the size of remaining white households, perhaps because larger households with children were more concerned about racial diversity. However, 
the change in household composition is small, resulting in the departure of 0.13 white residents for every new black arrival. ${ }^{19}$

Black in-migration led to a net reduction in the number of households in receiving cities. This decline could either result in vacancies in the existing housing stock or a decline in the housing stock itself as units depreciate and/or fewer new units are built. The model predicts that in otherwise declining areas, white departures will be coupled with a high vacancy rate and falling prices, whereas in growing areas, white departures will lead to a decline in the rate of new construction and housing prices will remain at construction costs. The second and third column separate the sample into low- and high-growth metropolitan areas (above or below the median growth rate of 58 percent from 1940-70). Consistent with this prediction, the arrival of 1,000 black households into a high growth area, which results in a net decline of 800 households, leads to 750 fewer housing units being built and only 50 units standing vacant. In contrast, 1,000 new black households in a low growth areas (a net decline of 700 households) is associated with 500 additional vacancies. I will show a similar pattern with respect to housing prices below.

\section{Assessing the quantitative role of white flight}

The estimated number of white departures for every black arrival allows us to calculate the likely effect of black migration on urban population loss. Let's begin with an extreme thought experiment: what if the four million black migrants had not left the South during this period? The median northern and western city received 19,000 black migrants from 1940 to 1970. The estimated response implies that 52,000 whites left the city as a result, translating into a 27 percent decline in the city's white population and a 17 percent decline in the total urban

\footnotetext{
${ }^{19}$ The arrival of 1,000 black households (= 3,500 residents) leads to -0.003 fewer residents in the average white household. In the typical city, this decline in household size translates into the loss of 448 residents. These figures imply that each new black resident results in the loss of 0.13 white residents.
} 
population. To put this magnitude into context, consider that Baum-Snow (2007) estimates that the construction of one new interstate highway through a central city leads to a similar 16 percent decline in urban population.

While this "no-migration" counterfactual is large, it is not entirely out of sample. The effect of shutting off the flow of black migrants is equivalent to imposing the growth rate of Pittsburgh's black population rather than that of Detroit's black population on the typical city (150 versus 440 percent). If instead one considers the difference in the black inflow between Detroit and Chicago (440 versus 400 percent), the median city would have experienced an eight percent decline in its white population. ${ }^{20}$

Can the estimated response to the black migration be wholly explained by the "tipping" of certain neighborhoods from majority white to majority black (Schelling, 1971)? In 1970, Card, Mas, and Rothstein (2008) estimate that neighborhoods tipped after reaching a 9-12 percent minority share. The estimated tipping point has increased over time, so the tipping point in 1950 might have been as low as, say, five percent. To assess the quantitative importance of this phenomenon, imagine that, in 1940, before the war-time migration, no neighborhood in sample metropolitan areas had yet reached the tipping point. By 1950, 5.8 percent of Census tracts in sample cities fell within the candidate range (five to 12 percent black). Card, Mas, and Rothstein document that neighborhoods directly above the tipping point lose 10-16 percent of their white population over the next decade relative to neighborhoods directly below. Let's take the case of the median city with 200,000 white residents who received 6,000 black arrivals over the 1940s. If all candidate neighborhoods lost 16 percent of their white population over the next

\footnotetext{
${ }^{20}$ Some blacks were attracted to the North by the availability of manufacturing work. If blacks had not filled these positions, others may have. One possibility is that blacks would have been replaced by Mexicans through an expansion of the Bracero guest worker program into urban areas. The white response to this alternative set of migrants is unknown.
} 
decade, this would translate into the departure of 1,856 white residents $(=200,000 \cdot 0.058 \cdot 0.16)$. The estimates suggest that a total of 16,200 white residents would have left the city in response to these black arrivals. 6,000 of these departures may be in direct response to higher housing prices. At most 20 percent of the remainder can be explained by neighborhood tipping $(=1,856 / 10,200)$. The remaining departures may have been in response to more continuous shifts in neighborhood composition or to changes in city-wide attributes.

\section{The effect of racial diversity on housing prices}

Thus far, I have shown that each black arrival to a central city at mid-century prompted more than one white departure. This pattern suggests that white mobility was not only a response to higher housing prices but also reflected a distaste for racial diversity. I can test this proposition directly by looking for a negative association between the black population share in the central city and the price of urban housing, again using the southern push instrument to predict black arrivals.

Aggregate data on housing values are available from 1950 to 1970. For these years, I estimate:

PRICE_CITY ${ }_{m r t}=\alpha_{m}+\beta_{2}($ PERB_CITY $m r t)+\gamma_{2}(\text { PRICE_METRO })_{m r t}+\Gamma^{\prime} \mathrm{X}_{m r t}+v_{r t}+\varepsilon_{m r t}$

where PERB_CITY measures the city's black population share. $\beta_{2}$ estimates the effect of urban diversity on the prices of city housing relative to metropolitan area-wide trends. The vector $\mathrm{X}_{m r t}$ contains average housing quality measures, including the median number of rooms in city housing units, the share of units that are in detached, single-family structures and the share of units that were built in the previous ten years. 
Table 4 examines the relationship between the black population share and the mean value of owner-occupied housing in the central city. The first column of Table 4 contains the basic specification, while the second adds housing quality controls for the Census of Housing. In both cases, an increase in the black population share of the central city reduces housing prices. In the raw data, a 10 percentage point increase in the black population share is associated with a six percent decline in housing prices. 20 percent of this decline can be explained by a limited set of housing quality controls. It is unlikely that the observed price decline was driven by lower prices paid by new black arrivals. Cutler, Glaeser and Vigdor (1999) show that, in this period, blacks actually paid more than whites for equivalent housing units, perhaps because blacks faced a supply constraint created by white households unwilling to sell to black buyers.

Again, one may be concerned that black migrants were attracted to areas with falling housing prices. In contrast, instrumenting with predicted migrant flows augments the negative relationship between racial diversity and urban housing prices (compare columns 2 and 3 ). ${ }^{21}$ If anything, black migrants seem to be attracted to cities with higher wages or amenities that translate into higher city housing prices.

Falling housing prices together with the decline in urban population is suggestive of a drop in the demand for cities that experience black in-migration. However, we would not expect housing prices to fall in all cities. In otherwise declining cities, falling demand may lead some existing units to stand vacant and housing prices to fall. In growing cities, a decline in urban demand may instead slow the rate of new construction until housing prices return to construction costs. As before, I split the sample by the rate of metropolitan area growth from 1940-70. Consistent with this reasoning, I find that increasing racial diversity has no effect on housing

\footnotetext{
${ }^{21}$ To instrument for the black population share, I use the city's population in 1940 as the denominator of the predicted black population share in all years to prevent a mechanical correlation arising between the instrument and the endogenous black population share.
} 
prices in growing cities, where, as we have already seen, the net decline in urban households resulted in fewer housing units being built (Table 3). In declining areas, by contrast, increasing racial diversity is associated with falling housing prices alongside a higher vacancy rate.

\section{Conclusion}

Black migration from the rural South to industrial cities in the North and West coincided with the development of postwar suburbs. Did black migrants happen to arrive in cities at the wrong time, just as suburbanization got underway? Or was their arrival an important explanation for suburban growth? This paper shows that cities that received more black migrants from 1940 to 1970 lost a greater number of white residents. I rule out explanations for this pattern based on the endogenous location decisions of black migrants or the effect of migration on urban housing prices alone. My estimates suggest that the change in racial diversity associated with black migration resulted in a 17 percent decline in urban population.

An ancillary goal of the paper has been to develop an instrument for changes in urban diversity in American cities over time. The instrument exploits shocks to southern industry and agriculture and the persistence of black migration patterns between southern states and northern cities. This method has many additional applications to questions in urban and public economics as well as to the economic history of American cities in the $20^{\text {th }}$ century.

While this paper quantifies the relationship between black arrivals and white departures from postwar cities, it has less to say about the mechanisms by which racial diversity affected the demand for urban residence. Some white residents were undoubtedly concerned about the changing racial and socio-economic composition of their immediate neighborhoods. However, many others lived in all-white enclaves far from burgeoning black ghettos. These residents may 
have been motivated by changes in local policy accompanying a shift in the racial and socioeconomic composition of the urban electorate. The desegregation of public schools in the 1960s and 1970s provided another reason to leave the city. Exploring these mechanisms offers a promising direction for future research. 


\section{Data Appendix}

\section{$\underline{\text { Northern Data }}$}

Sample selection: The sample includes all non-southern SMSAs that: (1) were anchored by one or more of the 100 largest cities in 1940 or (2) had at least 250,000 residents by 1970. Only two SMSAs that meet the first criterion fall short of the later population benchmark (Bridgeport, CT and New Bedford, MA). The second criterion adds 10 metropolitan areas to the sample, including growing western cities (e.g., Phoenix, AZ) and smaller areas in Pennsylvania, Ohio and upstate New York (e.g., Harrisburg, PA). Excluding these 10 areas has no discernable effect on the main results (compare a coefficient of $-2.110($ s.e. $=0.548)$ to the coefficient of interest in Table 2, column 2). For consistency, I apply the 1970 county-based definition of a metropolitan area in every year. I use the New England County Metropolitan Area (NECMA) classifications for the New England region to avoid divided counties.

Changes in city boundaries through annexation: City boundaries can expand through the annexation of neighboring territory (Jackson, 1985, p. 138-156; Dye, 1964). The direction of any bias created by annexation activity is unknown. Austin (1999) argues that politicians in diversifying cities have a stronger incentive to annex neighboring land in order to retain a majority-white electorate. In contrast, Alesina, Baqir and Hoxby (2004) find that racial diversity reduces the number of successful school district consolidations, particularly in states that require both districts to agree to consolidate.

To adjust for annexation, I create a parallel set of population counts that define central cities according to their 1940 borders. That is, I reassign residents who would have lived in the suburban ring if not for annexation back to the suburbs. ${ }^{22}$ Each measure involves a tradeoff. Counts based on actual borders might conceal patterns of individual mobility erased by annexation activity. However, counts based on consistent borders will misclassify moves from annexed city territory to the suburbs as suburb-to-suburb moves.

The tables in the paper are based on the fixed border population counts. Using actual city boundaries instead produces an estimate of 2.317 (s.e. $=0.609$ ) white departures for every black arrival. This coefficient is qualitatively similar to the comparable estimate in the second column of Table 1.

\section{$\underline{\text { Southern Data }}$}

Net black migration rates by county: Black migration rates are approximated from population counts in race-sex-age cohorts in two Censuses, adjusted by national survival ratios (Gardner and Cohen, 1971; Bowles, et al., 1990). That is, the actual population in a cohort in county $c$ at time $t$ is compared to a predicted population count determined by multiplying that cohort's population at time $t-10$ by the national survival ratio. The difference between the actual and predicted population counts are attributed to in- or out-migration. Even when measured by race, the national survival ratio may understate mortality in the South leading to an over-estimate of out-

\footnotetext{
${ }^{22}$ The Census Bureau estimated the number of individuals drawn into the central city through annexation from block level data (Bogue, 1953; US Census, 1960, 1970).
} 
migration (Fishback, Horrace and Kantor, 2005). As long as this bias is not systematically related to economic factors across counties, it should simply attenuate the coefficients.

Agricultural data by county: All southern county-level variables are drawn from the electronic County and City Data Books, with the exception of cotton acreage. Information on cotton acreage is available electronically for some states at the National Agricultural Statistical Service's historical data website (http://www.usda.gov/nass/pubs/histdata.htm) and for others at the website of the Population and Environment in the US Great Plains project of the ICPSR (http://www.icpsr.umich.edu/PLAINS/). The remainder were collected by hand from the Censuses of Agriculture. 


\section{Bibliography}

Alesina, Alberto, Reza Baqir, and Caroline Hoxby. "Political Jurisdictions in Heterogeneous Communities.” Journal of Political Economy, 112, 2004, pp. 348-396.

Alston, Lee J. "Tenure Choice in Southern Agriculture, 1930-1960.” Explorations in Economic History, 18, 1981, pp. 211-232.

Austin, D. Andrew. "Politics vs. Economics: Evidence from Municipal Annexation.” Journal of Urban Economics, 45, 1999, pp. 501-532.

Baum-Snow, Nathaniel. “Did Highways Cause Suburbanization?" Quarterly Journal of Economics, 122(2), 2007, pp. 775-805.

Bayer, Patrick, Robert McMillan, and Kim S. Reuben. "Residential Segregation in General Equilibrium." NBER Working Paper No. 11095. January, 2005.

Benabou, Roland. "Equity and Efficiency in Human Capital Investments: The Local Connection." Review of Economic Studies, 63(2), April 1996, pp. 237-264.

Bogue, Donald J. Population Growth in Standard Metropolitan Areas, 1900-1950. Washington, D.C.: Housing and Home Finance Agency, 1953.

Boustan, Leah Platt. "Escape from the City? The Role of Race, Income, and Local Public Goods in Postwar Suburbanization.” NBER Working Paper 13311, August 2007.

Bowles, Gladys K., James D. Tarver, Calvin L. Beale, and Everette S. Lee. Net Migration of the Population by Age, Sex, and Race, 1950-1970 [computer file]. ICPSR ed., Study no. 8493, 1990.

Bradford, David F. and Harry H. Kelejian. "An Econometric Model of the Flight to the Suburbs." Journal of Political Economy. 81(3), 1973, pp. 566-589.

Card, David. "Immigrant Inflows, Native Outflows, and the Local Market Impacts of Higher Immigration." Journal of Labor Economics, 19(1), 2001, pp. 22-64.

Card, David, Alexandre Mas, and Jesse Rothstein. “Tipping and the Dynamics of Segregation.” Quarterly Journal of Economics, 2008, pp. 177-218.

Carrington, William J., Enrica Detragiache, and Tara Vishwanath. "Migration with Endogenous Moving Costs." American Economic Review, 86(4), 1996, pp. 909-30.

Collins, William J. "When the Tide Turned: Immigration and the Delay of the Great Black Migration." Journal of Economic History, 57(3), Sept., 1997, pp. 607-632.

Crowder, Kyle. "The Racial Context of White Mobility: An Individual-Level Assessment of the White Flight Hypothesis.” Social Science Research, 29, pp. 223-57.

Cullen, Julie Berry and Steven D. Levitt. "Crime, Urban Flight, and the Consequences for Cities." Review of Economics and Statistics, 81(2), 1999, pp. 159-169. 
Cutler, David M., Edward L. Glaeser and Jacob Vigdor. "The Rise and Decline of the American Ghetto." Journal of Political Economy. 107(3), 1999, pp. 455-506.

Doms, Mark and Ethan Lewis. "Labor Supply and Personal Computer Adoption." Federal Reserve Bank of Philadelphia, Working Paper 06-10, June 2006.

Dye, Thomas R. "Urban Political Integration: Conditions Associated with Annexation In American Cities." Midwest Journal of Political Science. 8(4), 1964, pp. 430-446.

Ellen, Ingrid Gould. Sharing America's Neighborhoods: The Prospects for Stable Racial Integration. Cambridge: Harvard University Press, 2000.

Emerson, Michael O., Karen J. Chai and George Yancey. "Does Race Matter in Residential Segregation? Exploring the Preferences of White Americans." American Sociological Review, 66(6), 2001, pp. 922-935.

Fishback, Price, William Horrace and Shawn Kantor. "The Impact of New Deal Expenditures on Mobility During the Great Depression.” Explorations in Economic History, 43(2), 2006, pp. 179-222.

Fligstein, Neil. Going North: Migration of Blacks and Whites from the South, 1900-1950. New York: Academic Press, 1981.

Frey, William H. "Central City White Flight: Racial and Nonracial Causes." American Sociological Review. 44(3), 1979, pp. 425-448.

Gabriel, Stuart A., Janice Shack-Marquez and William L. Wascher. "Regional House-Price Dispersion and Interregional Migration.” Journal of Housing Economics, 2, 1992, pp. 235-256.

Gamm, Gerald H. Urban Exodus: Why the Jews Left Boston and the Catholics Stayed. Cambridge: Harvard University Press, 1999.

Gardner, John and William Cohen. County Level Demographic Characteristics of the Population of the United States: 1930-1950 [computer file]. Compiled by University of Chicago Center for Urban Studies. ICPSR ed, Study no. 0020, 1971.

Glaeser, Edward L. and Joseph Gyourko. "Urban Decline and Durable Housing." Journal of Political Economy, 113(2), 2005, pp. 345-375.

Gottlieb, Peter. Making Their Own Way: Southern Blacks' Migration to Pittsburgh: 1916-30. Urbana: University of Illinois Press, 1987.

Great Plains Research Project, Population and Environment in the U.S. Great Plains (web site), InterUniversity Consortium for Political and Social Research, September 2005, $<$ http://www.icpsr.umich.edu/PLAINS/>.

Grossman, James R. Land of Hope: Chicago, Black Southerners, and the Great Migration. Chicago: University of Chicago Press, 1989.

Grove, Wayne A. and Craig Heinicke, "Better Opportunities or Worse? The Demise of Cotton Harvest Labor, 1949-1964.” Journal of Economic History, 63(3), 2003, pp. 736-767. 
Grove, Wayne A. and Craig Heinicke, "Labor Markets, Regional Diversity, and Cotton Harvest Mechanization in the Post-World War II United States," Social Science History, 29(2), 2005, pp. 269-297.

Grubb, W. Norton. "The Flight to the Suburbs of Population and Employment, 1960-1970.” Journal of Urban Economics, 11, 1982, pp. 348-367.

Guterbock, Thomas M. "The Push Hypothesis: Minority Presence, Crime, and Urban Deconcentration." The Changing Face of the Suburbs, ed. Barry Schwartz. Chicago: The University of Chicago Press, 1976, pp. 137-161.

Jackson, Kenneth T. Crabgrass Frontier: The Suburbanization of the United States. New York: Oxford University Press, 1985.

Kopecky, Karen and Ming Hong Suen. "A Quantitative Analysis of Suburbanization and the Diffusion of the Automobile.” Manuscript, 2007.

LeRoy, Stephen and John Sonstelie. "Paradise Lost and Regained: Transportation Innovation, Income and Residential Location." Journal of Urban Economics, 13, 1983, pp. 67-89.

Lewis, Ethan. "Immigration, Skill Mix, and the Choice of Technique." Federal Reserve Bank of Philadelphia, Working Paper 05-08, May 2005.

Margo, Robert A. "Explaining the Postwar Suburbanization of Population in the United States: The Role of Income.” Journal of Urban Economics, 31(.), 1992, pp. 301-310.

Marshall, Harvey. "White Movement to the Suburbs: A Comparison of Explanations." American Sociological Review. 44(6), 1979, pp. 975-994.

Meyer, Stephen Grant. As Long As They Don't Move Next Door: Segregation and Racial Conflict in American Neighborhoods. New York: Rowman and Littlefield, Inc, 2000.

Mills, Edwin S. and Richard Price. "Metropolitan Suburbanization and Central City Problems." Journal of Urban Economics. 15(.), 1984, pp. 1-17.

Munshi, Kaivan. "Networks in the Modern Economy: Mexican Migrants in the US Labor Market." Quarterly Journal of Economics, 2003, p. 549-599.

National Agricultural Statistical Service, Historical Data (website), U.S. Department of Agriculture, Sept., 15, 2005, <http://www.usda.gov/nass/pubs/histdata.htm>.

Saiz, Albert. "Immigration and Housing Rents in American Cities." Journal of Urban Economics. 61, 2007, pp. 345-371.

Steinnes, Donald N. "Causality and Intraurban Location.” Journal of Urban Economics. 4(1), 1977, pp. 69-79.

Thurston, Lawrence and Anthony M. J. Yezer. "Causality in the Suburbanization of Population and Employment.” Journal of Urban Economics. 35, 1994, pp. 105-118. 
U.S. Bureau of the Census. $16^{\text {th }}$ Censuses of the United States: 1940, Internal Migration, 1935-40. Washington: Government Printing Office.

U.S. Bureau of the Census. $18^{\text {th }}$ and $19^{\text {th }}$ Censuses of the United States: 1960, and 1970, Geographic Mobility for Metropolitan Areas. Washington: Government Printing Office.

U.S. Bureau of the Census. County and City Data Book, Consolidated File: City/County Data, 19471977. ICPSR Study No. 7735-7736.

Whatley, Warren. "Labor for the Picking: The New Deal in the South." Journal of Economic History, 43(4), 1983, pp. 905-929.

Wright, Gavin. Old South, New South: Revolutions in the Southern Economy Since the Civil War. New York: Basic Books, 1986 
Figure 1: Change in black and white population in central city, 1950-60

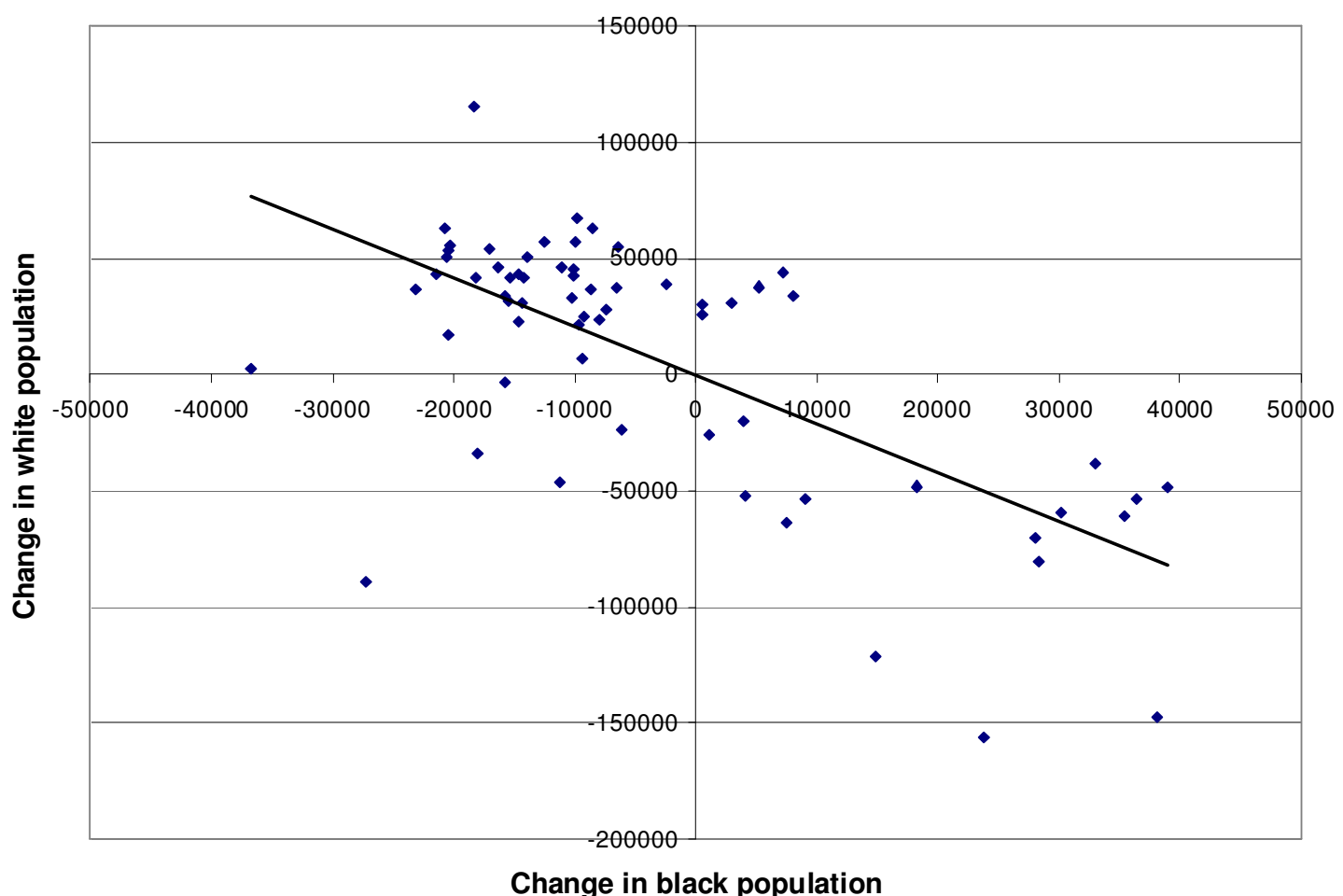

Notes: Each point in the scatter diagram represents the residual change in a city's black and white population after controlling for region fixed effects and changes in the metropolitan area's population over the decade. The slope of a regression line through these points is -2.010 (s.e. $=0.291$ ). While the four largest cities - Chicago, IL; Detroit, MI; Los Angeles, CA; and New York City, NY - are omitted for reasons of scale, they fall close to the regression line. With these cities included, the slope is -2.465 (s.e. = $0.132)$. 
Figure 2: Top destinations of northern black migrants from Alabama and Mississippi, 1935-40

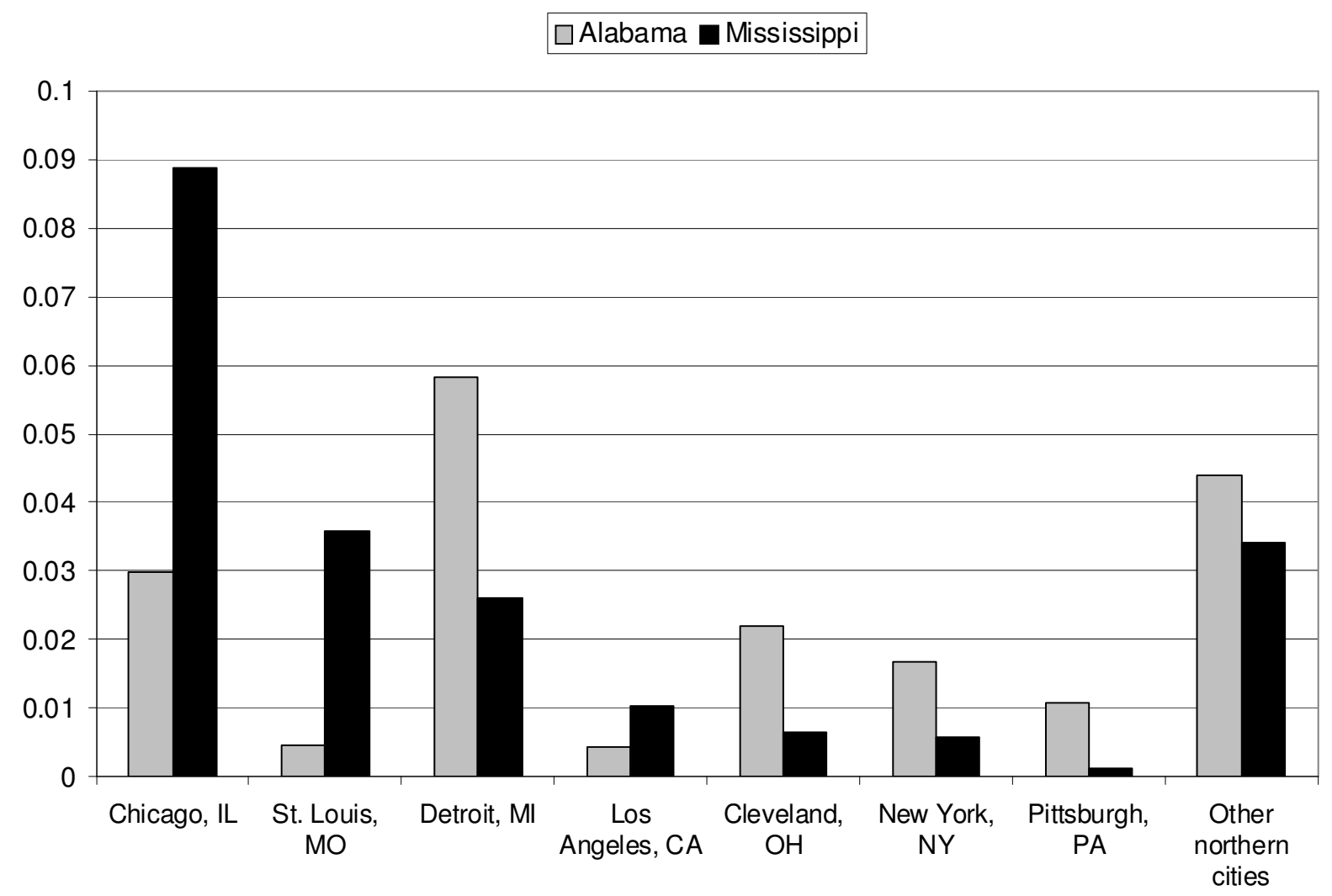

Notes: Data on migration flows are calculated from aggregate mobility tables from the 1940 Census (US Bureau of Census, Internal Migration, 1935-40). 
Figure 3: First stage, Predicted versus actual change in black population, 1950-60

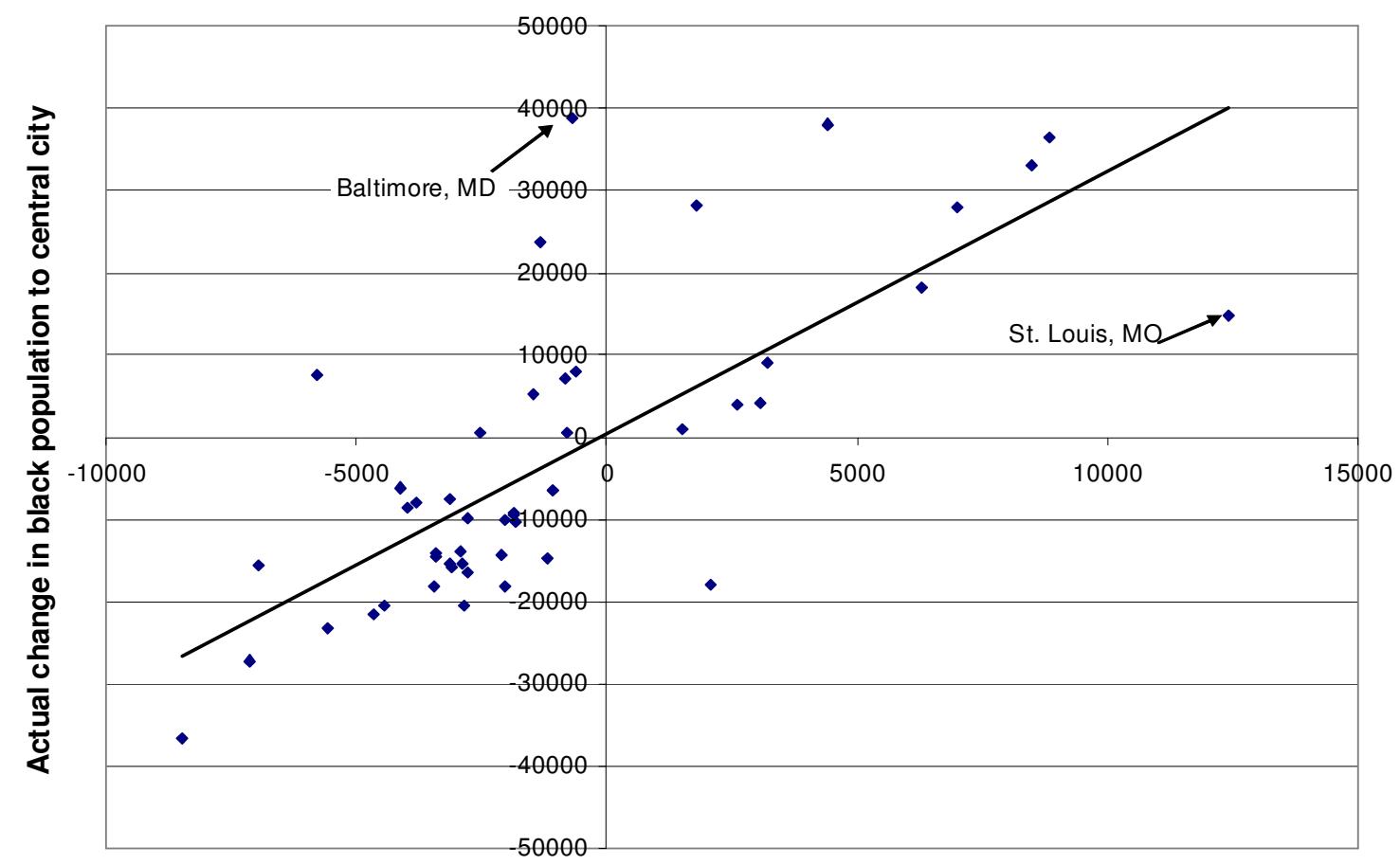

Predicted change in black population to central city

Notes: The sample includes the 53 SMSAs with available mobility counts by race in 1940 (without the four largest cities for reasons of scale). The predicted change in black population is calculated by assigning predicted migration flows from southern states to northern cities using 1935-40 settlement patterns. See Section III.B. for a detailed description of the instrument's construction. The slope of a regression line through these points is 3.187 (s.e. $=0.419)$. 
Table 1: Determinants of net black migration rates by southern county, 1940-1970

\begin{tabular}{|c|c|c|c|}
\hline & $1940-50$ & $1950-60$ & $1960-70$ \\
\hline Share land planted in cotton & $\begin{array}{l}-63.575 \\
(13.519)\end{array}$ & $\begin{array}{l}-9.695 \\
(7.064)\end{array}$ & $\begin{array}{l}-49.886 \\
(19.863)\end{array}$ \\
\hline Share farmers as tenants & $\begin{array}{l}-73.290 \\
(31.404)\end{array}$ & $\begin{array}{l}-22.836 \\
(15.778)\end{array}$ & $\begin{array}{l}-76.232 \\
(46.834)\end{array}$ \\
\hline Share agriculture & $\begin{array}{l}96.909 \\
(27.776)\end{array}$ & $\begin{array}{l}-144.440 \\
(100.353)\end{array}$ & $\begin{array}{l}159.350 \\
(47.875)\end{array}$ \\
\hline$=1$ if tobacco state & $\begin{array}{c}20.390 \\
(26.614)\end{array}$ & $\begin{array}{l}-60.438 \\
(58.781)\end{array}$ & $\begin{array}{c}45.501 \\
(20.783)\end{array}$ \\
\hline Sh agriculture $\cdot(=1$ tobacco $)$ & $\begin{array}{r}-119.379 \\
(49.753)\end{array}$ & $\begin{array}{c}185.865 \\
(169.730)\end{array}$ & $\begin{array}{r}-230.003 \\
(81.407)\end{array}$ \\
\hline Share mining & $\begin{array}{c}16.750 \\
(82.892)\end{array}$ & $\begin{array}{l}-63.233 \\
(36.631)\end{array}$ & $\begin{array}{c}59.030 \\
(73.275)\end{array}$ \\
\hline$=1$ if oil state & $\begin{array}{c}58.331 \\
(11.040)\end{array}$ & $\begin{array}{c}8.919 \\
(7.680)\end{array}$ & $\begin{array}{c}21.538 \\
(12.750)\end{array}$ \\
\hline Share mining $\cdot(=1$ if oil state $)$ & $\begin{array}{l}146.970 \\
(182.76)\end{array}$ & $\begin{array}{l}267.268 \\
(78.670)\end{array}$ & $\begin{array}{r}-126.308 \\
(98.638)\end{array}$ \\
\hline$\$$ in defense $p c, 1940-45$ & $\begin{array}{l}19.806 \\
(7.042)\end{array}$ & $\begin{array}{c}2.151 \\
(4.077)\end{array}$ & $\begin{array}{c}2.720 \\
(8.566)\end{array}$ \\
\hline Constant & $\begin{array}{c}16.377 \\
(14.330)\end{array}$ & $\begin{array}{c}40.695 \\
(33.557)\end{array}$ & $\begin{array}{c}-2.801 \\
(11.489)\end{array}$ \\
\hline $\mathrm{N}$ & 1378 & 1352 & 1350 \\
\hline
\end{tabular}

Notes: See Data Appendix for source details. Appendix Table 1 contains summary statistics. The dependent variable for each regression is the net black migration rate by southern county. 
Table 2:

Black migration to central cities and white population loss

\begin{tabular}{l|ccc}
\hline Dependent variable: & $\begin{array}{l}\text { Actual black } \\
\text { population in city }\end{array}$ & White population in city \\
Instrument type & First stage & OLS & -2.365 \\
\hline Assign actual migrants & 4.442 & -2.099 & $(0.805)$ \\
& $(0.652)$ & $(0.549)$ & -2.627 \\
Assign predicted migrants, 1940-70 & 3.466 & -2.099 & $(0.782)$ \\
& $(0.671)$ & $(0.549)$ & -2.983 \\
Assign predicted migrants, 1950-70 & 4.488 & -2.278 & $(0.768)$ \\
& $(0.968)$ & $(0.604)$ & -3.085 \\
Predict with 1940 variables, 1950-70 & 4.365 & -2.278 & $(0.708)$ \\
& $(0.799)$ & $(0.604)$ & -1.050 \\
Long-run changes, 1940-2000 & 6.800 & -0.771 & $(0.199)$ \\
& $(0.421)$ & $(0.166)$ & 0.169 \\
Long-run changes, White foreign- & & & $(0.078)$ \\
born population in the city & --- & $(0.066)$ & \\
\hline
\end{tabular}

Notes: Standard errors are clustered by SMSA and reported in parentheses. Standard errors are bootstrapped when using the generated instrument (rows 2-6). The sample includes 53 SMSAs with published 1935-40 mobility counts by race from $1940-1970(\mathrm{~N}=212)$ or $1950-1970(\mathrm{~N}=159)$. The instrument in the first row assigns actual migration flows out of southern states to northern cities according to the 1935-40 settlement patterns. The instrument in the second through sixth rows assign predicted migration flows. Section III.B. contains a detailed description of the instrument's construction. The fourth row uses county characteristics from 1940 to predict out-migration in the 1950s and 1960s. The fifth (sixth) row estimates the relationship between the change in white (foreign-born white) and black populations in the central city from 1940 to 2000. 
Table 3:

Black households, white households and the number of housing units in central cities

\begin{tabular}{l|ccc}
\multicolumn{4}{c}{ Coefficient on \# of black households (in 1,000s) } \\
\hline Dependent variables & Full sample & Low growth metro & High growth metro \\
\hline 1. \# white households & -1602.495 & -1715.816 & -1790.906 \\
& $(178.513)$ & $(271.964)$ & $(433.305)$ \\
2. White household size & -0.003 & -0.0009 & -0.004 \\
& $(0.0007)$ & $(0.0006)$ & $(0.001)$ \\
& $(448$ residents $)$ & $(164$ residents $)$ & $(475$ residents $)$ \\
3. \# housing units & -559.562 & -202.652 & -747.981 \\
& $(211.192)$ & $(237.212)$ & $(414.455)$ \\
4. \# of vacant units & 46.192 & 513.163 & 47.328 \\
& $(168.318)$ & $(61.391)$ & $(24.982)$ \\
$\mathrm{N}$ & 280 & 140 & 140 \\
\hline
\end{tabular}

Notes: Standard errors are clustered by SMSA and are reported in parentheses. The number of black and white households and the number of housing units are from the Census of Housing for relevant years. The second and third columns split the sample by the metropolitan area growth rate from 1940 to 1970 (median = 58 percent). In the second row, household size is translated into the number of white residents lost using the average number of white households $(149,400,182,200$ and 118,750 in the three columns respectively). 
Table 4:

Black population share and the value of owner-occupied housing in the city, 1950-70

\begin{tabular}{l|ccccc}
\hline & \multicolumn{2}{|c}{ OLS } & IV & Low & High \\
& & & & growth & growth \\
& $(1)$ & $(2)$ & $(3)$ & $(4)$ & $(5)$ \\
\hline Black population share in city & -0.610 & -0.470 & -0.689 & -0.618 & 0.030 \\
& $(0.227)$ & $(0.194)$ & $(0.108)$ & $(0.266)$ & $(0.295)$ \\
& & & & & \\
Housing controls & $\mathrm{N}$ & $\mathrm{Y}$ & $\mathrm{Y}$ & $\mathrm{Y}$ & $\mathrm{Y}$ \\
$N$ & 159 & 159 & 159 & 99 & 102 \\
\hline
\end{tabular}

Notes: Standard errors are clustered by SMSA and are reported in parentheses. Housing quality controls include the median number of rooms, the share of housing units that are in detached, single-family buildings and the share of housing units that were built in the previous ten years. The fourth and fifth columns split the sample by the metropolitan area growth rate from 1940 to 1970 (median $=58$ percent). 


\section{Appendix Table 1:}

Summary statistics for $1940-1960,1350$ southern counties

\begin{tabular}{l|cccc}
\hline & Mean & Std. Dev. & Min & Max \\
\hline Net black migration rate & 1.811 & 147.253 & -100 & 4400 \\
Share land in cotton & 0.329 & 0.397 & 0 & 1 \\
Share farmers as tenant & 0.312 & 0.195 & 0 & 0.942 \\
Share LF in agriculture & 0.335 & 0.183 & 0.001 & 0.885 \\
Share LF in mining & 0.028 & 0.074 & 0 & 0.818 \\
\$ defense $p c, 1940-45$ & 0.162 & 0.599 & 0 & 9.025 \\
\hline
\end{tabular}

Note: See Data Appendix for source details. Spending on defense contracts in current dollars. 
Appendix Table 2:

Summary statistics for 1940-1970, 70 non-southern metropolitan areas

\begin{tabular}{|c|c|c|}
\hline & Mean & Standard Deviation \\
\hline $\begin{array}{l}\text { Population } \\
\text { Whites in city }\end{array}$ & 457,107 & 919,030 \\
\hline$\Delta$ whites in city & $-16,158$ & 100,509 \\
\hline Blacks in city & 70,877 & 182,963 \\
\hline$\Delta$ blacks in city & 28,209 & 68,553 \\
\hline Share black & 0.092 & 0.093 \\
\hline Total in SMSA & $1,289,456$ & $3,238,178$ \\
\hline $\begin{array}{l}\text { Instrument } \\
\text { Predicted black population }\end{array}$ & 48,834 & 102,440 \\
\hline Predicted $\Delta$ black & 5,703 & 12,687 \\
\hline $\begin{array}{l}\text { Households } \\
\text { Whites in city }\end{array}$ & 149,491 & 295,826 \\
\hline$\Delta$ whites in city & 10,232 & 34,177 \\
\hline Blacks in city & 20,552 & 54,172 \\
\hline$\Delta$ blacks in city & 8,440 & 22,097 \\
\hline Vacant units & 7,724 & 16,429 \\
\hline
\end{tabular}

Notes: Statistics are presented for the 70 SMSAs in the North or West that were either (1) anchored by one of the 100 largest cities in 1940 or (2) that had at least 250,000 residents by 1970. The white and black population are calculated for counterfactual city borders. The borders are created by reassigning residents who would have lived in the suburbs if not for annexation back to the suburbs, under the assumption that the population living in the annexed area had the same white share as the suburban area as a whole. 